\title{
Editorial Policy Update
}

You will recall that shortly after I assumed the editorship of SuRveYs, we announced a new editorial policy which was published in our March 1973 issue. During the past three years we have completed a transition from a journal of largely invited papers paid for with substantial honoraria to a journal of mainly contributed papers. Strict standards based on careful refereeing and patient interaction among authors, referees, and editors have allowed us to maintain high standards. We have also begun to offer special issues on topics of broad interest, thanks to the willingness of several already busy professionals to serve as Guest Editors.

However, one thing we have not yet managed to do is to increase substantially the number of high-quality papers published annually ( 8 to 12 per year). There is no theoretical reason why we should continue to be so limited. As a major step in the search for more good papers for SurveYs, we are now pleased to announce formation of an Editorial Board for Surveys. Members of this Board are listed on the masthead. Each member has been invited to serve a term of up to three years and will be pleased to receive manuscripts from authors or proposals for manuscripts. Board members may elect to serve as editors for papers they receive, or forward them to the Editor-in-Chief for processing. Whether an author chooses to send his paper to the Editor-in-Chief or directly to a member of the Editorial Board, he is assured of equivalent attention and service.

-Euliott I. Organick 